\title{
Nadciśnienie płucne w przebiegu chorób lewego serca - aktualne leczenie i kierunki rozwoju terapii
}

\author{
Pulmonary hypertension due to left heart disease \\ - review of the treatment and directions of development
}

\author{
Danuta Karasek, Władysław Sinkiewicz
}

II Katedra Kardiologii Collegium Medicum w Bydgoszczy, Uniwersytet Mikołaja Kopernika w Toruniu

\section{Streszczenie}

Przewlekła niewydolność serca jest schorzeniem nabierającym coraz większego znaczenia. Pomimo istotnych postępów wyniki leczenia w tej grupie chorych są wciąż niezadowalające. Groźnym czynnikiem znacząco pogarszającym jakość życia chorych z niewydolnością serca, zwiększającym ryzyko hospitalizacji i zgonu jest nadciśnienie płucne. Nadciśnienie płucne związane z chorobami lewego serca (PH-LHD) wynika z zaburzeń funkcji skurczowej i rozkurczowej lewej komory, które prowadzą do wzrostu ciśnienia napełniania lewej połowy serca. Zapoczątkowuje to wiele niekorzystnych zmian patofizjologicznych i czynnościowych w krążeniu płucnym i w prawym sercu. Rozpoznanie i leczenie nadciśnienia płucnego jest trudne. Na szczęście rozwój badań diagnostycznych, zharmonizowana terminologia i nowa klasyfikacja PH-LHD pozwalają na lepszą diagnostykę i kwalifikację chorych do właściwej grupy. Kluczowe znaczenie w rozpoznaniu nadciśnienia płucnego i odpowiedniej jego klasyfikacji ma cewnikowanie serca. Większość terapii celowanych w PH jest przeznaczona dla osób z tętniczym nadciśnieniem płucnym, a zastosowanie tych leków w PH-LHD nie zostało dostatecznie zbadane w randomizowanych badaniach klinicznych lub wykazano wręcz szkodliwe ich działanie w tej grupie chorych. Istnieje wyraźna potrzeba dalszych badań nad mechanizmami leżącymi u podstaw PH-LHD i nowych opcji terapeutycznych, które pomogą stymulować rozwój nowych wytycznych leczenia tej grupy chorych.

Słowa kluczowe: niewydolność serca, nadciśnienie płucne

Folia Cardiologica 2017; 12, 3: 317-325

\section{Wstęp}

Nadciśnienie płucne (PH, pulmonary hypertension) jest stanem hemodynamicznym, który występuje w przebiegu różnych schorzeń. Najbardziej rozpowszechnioną formą $\mathrm{PH}$ jest nadciśnienie płucne związane z chorobami lewego serca (PH-LHD, pulmonary hypertension in left heart disease), stanowiąc 65-80\% przypadków. Rozwój $\mathrm{PH}$ u pacjentów z przewlekłą niewydolnością serca (HF, heart failure) jest czynnikiem znacząco pogarszającym jakość ich życia, zwiększającym ryzyko hospitalizacji i zgonu, niezależnie od wielkości frakcji wyrzutowej lewej komory (LVEF, left ventricular ejection fraction) i stadium choroby [1].

W PH-LHD dochodzi do wzrostu ciśnienia napełniania lewej komory, aktywnej wazokonstrykcji naczyń płucnych i ich remodelingu. Nieprawidłowe parametry hemodynamiczne u chorych z HF mogą stanowić potencjalny cel terapeutyczny. Większość terapii celowanych w PH jest przeznaczona dla osób z tętniczym nadciśnieniem płucnym (PAH, pulmonary arterial hypertension), a zastosowanie tych leków w PH-LHD nie zostało dostatecznie zbadane w randomizowanych badaniach klinicznych lub wykazano wręcz szkodliwe ich działanie w tej grupie chorych [2]. 
Tabela 1. Definicje hemodynamiczne nadciśnienia płucnego (PH, pulmonary hypertension)

\begin{tabular}{|c|c|c|}
\hline Definicja & Cechy & Grupa kliniczna \\
\hline Nadciśnienie płucne (PH) & $\mathrm{mPAP} \geq 25 \mathrm{~mm} \mathrm{Hg}$ & Wszystkie \\
\hline \multirow[t]{4}{*}{ Przedwłośniczkowe PH } & $\mathrm{mPAP} \geq 25 \mathrm{~mm} \mathrm{Hg}$ & 1. Tętnicze nadciśnienie płucne \\
\hline & $\mathrm{PAWP} \leq 15 \mathrm{~mm} \mathrm{Hg}$ & 3. PH w przebiegu chorób płuc \\
\hline & & 4. Przewlekłe zatorowo-zakrzepowe PH \\
\hline & & $\begin{array}{l}\text { 5. PH o niejasnym i/lub wieloczynnikowym patome- } \\
\text { chanizmie }\end{array}$ \\
\hline \multirow[t]{2}{*}{ Pozawłośniczkowe PH } & $m P A P \geq 25 \mathrm{~mm} \mathrm{Hg}$ & 2. PH w przebiegu chorób lewego serca \\
\hline & PAWP > 15 mm Hg & 5. PH o niejasnym i/lub wieloczynnikowym patome- \\
\hline \multirow[t]{2}{*}{ Izolowane pozawłośniczkowe PH (Ipc-PH) } & $\mathrm{DPG}<7 \mathrm{mmHg} \mathrm{i} / \mathrm{lub}$ & \\
\hline & $\mathrm{PVR} \leq 3 \mathrm{WU}$ & \\
\hline \multirow[t]{2}{*}{ Złożone przed- i pozawłośniczkowe PH (Cpc-PH) } & DPG $\geq 7$ mmHg i/lub & \\
\hline & PVR > 3 WU & \\
\hline
\end{tabular}

\section{Definicja i klasyfikacja hemodynamiczna}

Niezależnie od etiologii PH jest definiowane jako podwyższone średnie ciśnienie w tętnicy płucnej (mPAP, mean pulmonary artery pressure) większe lub równe $25 \mathrm{~mm} \mathrm{Hg}$ w spoczynku, oznaczone podczas cewnikowania prawego serca (RHC, right heart catherization) [3].

$\mathrm{Na}$ podstawie ciśnienia napełniania lewej komory określanego przez końcoworozkurczowe ciśnienie w lewej komorze (LVEDP, left ventricular end-diastolic pressure) lub ciśnienie zaklinowania w tętnicy płucnej (PAWP, pulmonary arterial wedge pressure) wyróżnia się dalsze podtypy hemodynamiczne nadciśnienia płucnego - prekapilarne/ /przedwłośniczkowe PH (PAWP $\leq 15$ mm Hg) i postkapilarne/ /pozawłośniczkowe PH (PAWP >15 mm Hg). W postkapilarnym PH wzrost PAWP powoduje proporcjonalny wzrost mPAP, utrzymując prawidłowy gradient przezpłucny (TPG, transpulmonary pressure gradient $=\mathrm{mPAP}-\mathrm{PAWP})$ poniżej $12 \mathrm{~mm} \mathrm{Hg}$ i niski naczyniowy opór płucny (PVR, pulmonary vascular resistance) - mniej niż 3 jednostki Wooda $\left(<240\right.$ dyn $\left.\times \mathrm{s} \times \mathrm{cm}^{-5}\right)$ [4].

Dopóki dominującą przyczyną podwyższonego średniego PAP jest ciśnienie poniżej tętnic płucnych, PH-LHD uważane jest za bierne, TPG i PVR są wówczas prawidłowe. Ten typ PH występuje najczęściej w pierwszych etapach HF. Przewlekle podwyższone ciśnienie napełniania lewej komory związane z aktywacją neurohormonalną oraz wtórną aktywacją mediatorów mogą powodować nadmierną wazokonstrykcję naczyń z lub bez ich przebudowy, co prowadzi do nieproporcjonalnie wysokiego wzrostu PAP. Rezultatem tego jest wzrost TPG i PVR, które opisywano jako reaktywne/mieszane $\mathrm{PH}$. Jak stwierdzono, TPG zależy od obciążenia objętościowego oraz funkcji serca i nie ma znaczenia prognostycznego dla przebiegu PH-LHD. Gradient ciśnienia rozkurczowego (DPG, diastolic pressure gradient) natomiast, definiowany jako różnica między rozkurczowym PAP i PAWP, jest istotnie mniej zależny od objętości wyrzutowej i warunków napełniania, a jego wartość koreluje ze stopniem remodelingu naczyń płucnych w PH-LHD. Te odkrycia doprowadziły do zmiany w najnowszych wytycznych aktualnej terminologii i klasyfikacji postkapilarnego nadciśnienia płucnego. Wyróżniono izolowane postkapilarne nadciśnienie płucne (Ipc-PH, isolated post-capillary pulmonary hypertension) oraz złożone pre- i postkapilarne $\mathrm{PH}$ (Cpc-PH, combined post-capillary pulmonary hypertension) [5] (tab. 1).

\section{Epidemiologia ì znaczenie kliniczne}

Autorzy nie dysponują epidemiologicznymi danymi porównawczymi dotyczącymi chorobowości poszczególnych grup $\mathrm{PH}$. W badaniu ankietowym przeprowadzonym w pracowni echokardiograficznej częstość PH definiowanego jako skurczowe PAP (sPAP, systolic PAP) ponad $40 \mathrm{~mm}$ Hg wśród 4579 chorych wynosiła 10,5\%, w tym 78,7\% stanowili pacjenci z PH-LHD, u 9,7\% chorych stwierdzono choroby płuc i hipoksję, 4,2\% miało $\mathrm{PAH}, \mathrm{u}$ 0,6\% rozpoznano zakrzepowo-zatorowe PH, zaś u 6,8\% pacjentów nie ustalono przyczyny PH [8]. Obserwacje wskazują, że nadciśnienie płucne może się rozwinąć u około $70 \%$ chorych z izolowaną ciężką dysfunkcją rozkurczową i do 60\% chorych z niewydolnością serca z upośledzoną frakcją wyrzutową lewej komory (HFREF, heart failure with reduced ejection fraction) [6]. 
Częstość występowania PH wśród pacjentów z niewydolnością lewej komory wzrasta wraz z postępem upośledzenia wydolności fizycznej wyrażonego klasą czynnościową New York Heart Association (NYHA). Wśród pacjentów z HFREF nadciśnienie płucne oceniane w RHC szacuje się na 40-75\%; według innych źródeł w zależności od badanej populacji oraz stosowanych kryteriów częstość waha się między 16 a 63\% [7]. U chorych z niewydolnością serca z zachowaną frakcją wyrzutową (HFPEF, heart failure with preserved ejection fraction) ostatnie badania z wykorzystaniem echokardiografii i RHC wskazują na występowanie $\mathrm{PH}$ u 36-83\% [8]. Należy podkreślić, że definiowanie PH jako wartości sPAP ponad $35 \mathrm{~mm}$ Hg zmierzonego podczas badania echokardiograficznego wiąże się z dużą liczbą rozpoznań fałszywie dodatnich.

Rozwój PH u osób z chorobami lewego serca wiąże się ze złym rokowaniem. Badania populacyjne wykazały, że szacowana w badaniu echokardiograficznym wartość sPAP u pacjentów z HF ma silną wartość predykcyjną śmiertelności ogólnej oraz zgonów sercowo-naczyniowych. Nadciśnienie płucne jest niezależnym czynnikiem ryzyka zgonu u chorych z kardiomiopatią rozstrzeniową, stabilną chorobą wieńcową i po zawale serca [9]. Parametry hemodynamiczne będące predyktorami gorszego przeżycia w HF to podwyższone PAWP, mPAP i PVR [10]. Bursi i wsp. wykazali, iż wzrost wartości sPAP o każde $5 \mathrm{~mm}$ Hg wiązało się z 6\% wzrostem ryzyka zgonu [11].

\section{Patofizjologia}

Mechanizmy leżące u podstaw patogenezy PH-LHD wydają się liczne, niejednorodne i niezupełnie zrozumiałe. Kaskada zdarzeń rozpoczyna się wraz ze wzrostem ciśnienia napełniania lewego serca, co prowadzi do biernego wstecznego przenoszenia ciśnienia do układu żył płucnych. Czynnikiem dodatkowo sprzyjającym wzrostowi ciśnienia w lewym przedsionku, szczególnie podczas wysiłku fizycznego, jest czynnościowa niedomykalność zastawki mitralnej [12].

Przewlekle utrzymujące się podwyższone ciśnienie napełniania lewych jam serca oraz wzrost ciśnienia w żyłach płucnych może istotnie wpływać na brak równowagi w produkcji naczynioaktywnych mediatorów, takich jak tlenek azotu (NO, nitric oxide) i endotelina 1 (ET-1). Zmniejszenie produkcji NO, zwiększenie ekspresji ET-1, zmniejszenie wrażliwości na naczyniorozszerzające działanie peptydów natriuretycznych, nacieki komórek zapalnych oraz czynniki neurogenne to zjawiska powodujące istotne upośledzenie relaksacji mięśni gładkich naczyń [13]. Prowadzi to z czasem do patologicznej przebudowy tętnic płucnych, w tym muskularyzacji małych oporowych tętniczek płucnych, przerostu ich błony środkowej i tworzenia neointimy. Obie składowe - aktywny wzrost napięcia błony mięśniowej i przebudowa ściany - prowadzą do wzrostu PVR. Rozwija się złożone pre- i postkapilarne PH [14].
Podwyższone ciśnienie w łożysku płucnym powoduje wzrost obciążenia następczego prawej komory. Prawa komora (RV, right ventricle) dostosowuje się do zwiększonego obciążenia i dąży do utrzymania wyrzutu początkowo poprzez przerost ścian. W dalszej kolejności, jeśli przeciążenie się utrzymuje, dochodzi do włóknienia mięśnia RV, obniżenia jej kurczliwości, rozstrzeni i zmiany kształtu z półksiężycowatego na kulisty. To wiąże się z rozwojem czynnościowej niedomykalności zastawki trójdzielnej i nieodwracalnej niewydolności RV. Dysfunkcja RV i niedomykalność zastawki trójdzielnej nasila objawy HF i prowadzi do zwiększenia ciśnienia w prawym przedsionku, co sprzyja obrzękom, wpływa na zwiększone uwalnianie peptydów natriuretycznych i rozwój zastoju żylnego wraz z niewydolnością nerek. Pojawienie się niewydolności RV jest znane jako jeden z najbardziej znaczących niekorzystnych modyfikatorów rokowania u chorych z HF [15]. Podwyższenie PAP w HF wraz z niewydolnością RV ma większe znaczenie prognostyczne niż LVEF. Zależność między wielkością PAP i dysfunkcją RV nie jest liniowa, gdyż niektórzy pacjenci mimo wysokiego $\mathrm{PH}$ zachowują prawidłową funkcję RV (ryc. 1) [16].

\section{Rozpoznanie $\mathrm{PH}$ - metody nieinwazyjne i inwazyjne oraz ich ograniczenia}

Manifestacja kliniczna PH nie jest charakterystyczna. Dominują nasilające się objawy HF, początkowo lewokomorowej (duszność, męczliwość, osłabienie, bóle w klatce piersiowej, kaszel), następnie także prawokomorowej (poszerzenie żył szyjnych, obrzęki obwodowe, hepatomegalia, powiększanie obwodu brzucha). W skrajnie zaawansowanym okresie choroby mogą występować krwioplucia, chrypka, sinica [17].

Do czynników predysponujących do wystąpienia $\mathrm{PH}$ u osób z chorobą lewego serca należą: starszy wiek (> 65 rż.), podwyższone ciśnienie tętnicze krwi, podwyższone ciśnienie tętna, otyłość, choroba niedokrwienna serca, cukrzyca, migotanie przedsionków. Klinicznie pacjenci mogą manifestować objawy niespotykane powszechnie w innych postaciach PH, takie jak duszność typu ortopnoe, napadowa duszność nocna. W badaniu radiologicznym (RTG) klatki piersiowej mogą być widoczne cechy zastoju żylnego, obrzęku płuc lub płyn w jamie opłucnej. W badaniu EKG można się spodziewać cech przerostu mięśnia lewej komory [18] (tab. 2).

Zalecanym badaniem przesiewowym w rozpoznawaniu PH w przebiegu chorób lewego serca jest echokardiografia. Umożliwia ona pomiar różnych parametrów korelujących z hemodynamiką prawego serca i zawsze należy ją wykonać w przypadku podejrzenia PH [19]. W celu potwierdzenia obecności PH, określenia jego charakteru, oceny ciężkości zmian hemodynamicznych oraz wazoreaktywności krążenia płucnego niezbędne jest wykonanie prawostronnego cewnikowania serca. W doświadczonych ośrodkach cechuje się ono małą częstością powikłań $(1,1 \%)$ i śmiertelnością 


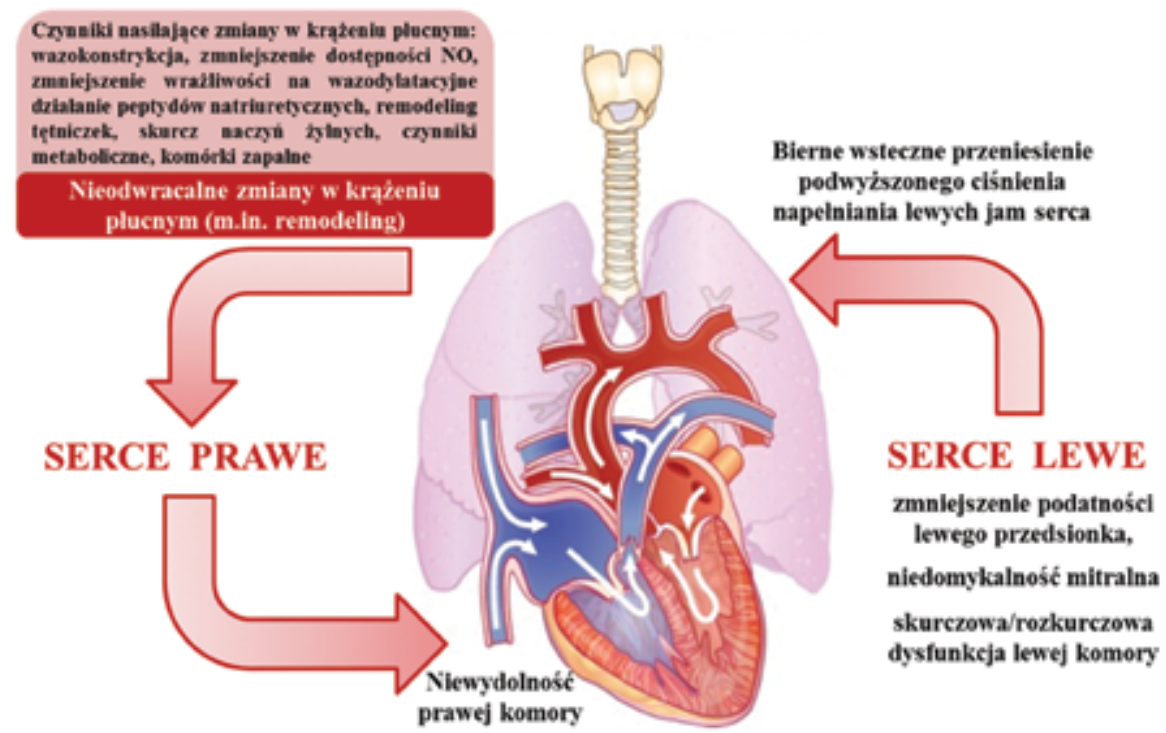

Rycina 1. Patofizjologia rozwoju nadciśnienia płucnego w lewokomorowej niewydolności serca; NO (nitric oxide) - tlenek azotu (na podstawie [16])

Tabela 2. Różnicowanie między tętniczym nadciśnieniem płucnym (PAH, pulmonary arterial hypertension) a i nadciśnieniem płucnym związanym z chorobami lewego serca (PH-LHD, pulmonary hypertension in left heart disease) na podstawie obrazu klinicznego i wyników podstawowych badań nieinwazyjnych

\begin{tabular}{|c|c|c|}
\hline & Prawdopodobne PAH & Prawdopodobne PH-LHD \\
\hline Obraz kliniczny & $\begin{array}{l}\text { Młodszy wiek, obciążony wywiad rodzinny, czynniki } \\
\text { ryzyka PAH - choroba tkanki łącznej, wada serca, } \\
\text { ciężkie choroby wątroby, nadciśnienie wrotne, HIV }\end{array}$ & $\begin{array}{l}\text { Starszy wiek, nadciśnienie tętnicze, cukrzyca, choroba } \\
\text { niedokrwienna serca, otyłość, zastój w krążeniu płucnym, } \\
\text { obrzęk płuc w wywiadzie, ortopnoe }\end{array}$ \\
\hline EKG & Cechy przerostu prawej komory, prawogram & $\begin{array}{l}\text { Cechy przerostu lewej komory, lewogram, migotanie } \\
\text { przedsionków }\end{array}$ \\
\hline $\mathrm{ECHO}$ & $\begin{array}{l}\text { Brak wykładników choroby lewego serca, podwyż- } \\
\text { szone sPAP, RV > LV, przerost/dysfunkcja RV, RVOT } \\
\text { notching, mały LA, poszerzona żyła główna dolna }\end{array}$ & $\begin{array}{l}\text { Powiększenie LA, przerost mięśnia lewej komory, objawy } \\
\text { skurczowej/rozkurczowej dysfunkcji lewej komory, wada } \\
\text { zastawkowa }\end{array}$ \\
\hline $\begin{array}{l}\text { RTG klatki } \\
\text { piersiowej }\end{array}$ & $\begin{array}{l}\text { Powiększenie RV, poszerzenie pnia płucnego, skąpy } \\
\text { rysunek naczyń obwodowych }\end{array}$ & $\begin{array}{l}\text { Zastój w krążeniu płucnym, linie Kerleya B, płyn w opłuc- } \\
\text { nej, powiększenie lewej komory serca }\end{array}$ \\
\hline
\end{tabular}

(0,055\%) [20]. Do różnicowania nadciśnienia płucnego związanego z chorobami lewego serca konieczne jest uzyskanie dobrej jakości zapisu PAWP. W rzadkich przypadkach może zaistnieć potrzeba cewnikowania lewego serca w celu uzyskania bezpośrednich LVEDP [21].

Zgodnie z wytycznymi cechą różnicującą PH-LHD od PAH jest stwierdzenie PAWP ponad $15 \mathrm{~mm} \mathrm{Hg}$. Pomiar PAWP ma bezpośredni wpływ na klasyfikację PH i decyzje terapeutyczne. Niestety, istnieje wiele ograniczeń i niejasności obejmujących wartość progową PAWP, która rozróżnia pre- i postkapilarne $\mathrm{PH}$, trudności techniczne przy uzyskiwaniu prawidłowego zapisu krzywej ciśnienia, a także brak odpowiedniej standaryzacji oraz zalecanej metody odczytu PAWP w stosunku do cyklu oddechowego [22]. Wydaje się, że końcowowydechowe pomiary PAWP są lepsze do różnicowania między PAH i HFPEF, zaś wartości średnie sa bardziej dokładne w grupie chorych z przewlekłą obturacyjną chorobą płuc (COPD, chronic obstructive pulmonary disease), u których wahania oddechowe są zwykle większe. W praktyce klinicznej błędnych klasyfikacji PH-LHD jako PAH i niewłaściwego leczenia tych pacjentów lekami celowanymi dla PAH jest istotnie więcej niż na odwrót $[23,24]$.

Ciśnienie zaklinowania w tętnicy płucnej uznaje się za równoważnik LVEDP. Opieranie się na pomiarach PAWP często prowadzi jednak do zaniżania wartości LVEDP i może być przyczyną błędu diagnostycznego. W dużym badaniu obejmującym ponad 4000 chorych z PH, około połowa osób, u których na podstawie pomiarów PAWP rozpoznano 
PAH, okazywała się mieć PH-LHD, kiedy oceniono LVEDP. Jednakże rutynowe oznaczanie LVEDV podczas cewnikowania serca niesie ze sobą zwiększone ryzyko powikłań, większe niedogodności dla pacjentów oraz wyższe koszty. Bezpośredni pomiar LVEDP należy rozważyć u pacjentów z dużym prawdopodobieństwem istotnej dysfunkcji lewej komory i granicznymi wartościami PAWP lub jeśli PAWP nie można zmierzyć w sposób wiarygodny [25].

\section{Leczenie i kierunki rozwoju}

Niekorzystne znaczenie rokownicze PH i dysfunkcji RV u chorych z HF uzasadnia przyjęcie za cel redukcję jego wartości jako potencjalną dodatkową opcję terapeutyczną zarówno u chorych z niewydolnością serca ze zmniejszoną, jak i zachowaną frakcją wyrzutową lewej komory. Ważne jest, aby dokładnie określić przyczynę PH przed podjęciem jakichkolwiek decyzji terapeutycznych. W przeciwieństwie do postępu, jaki dokonał się w ostatnich latach w terapii PAH, praktycznie nie poczyniono żadnych odkryć w leczeniu chorych z PH-LHD, nie istnieje swoista terapia PH w tej grupie chorych [26]. Wytyczne towarzystw naukowych podkreślają, że postępowanie w PH-LHD powinno mieć na celu optymalne leczenie choroby podstawowej. Nadciśnienie płucne nie stanowi przeciwwskazania do stosowania jakiegokolwiek leku rekomendowanego w leczeniu HF. Leki krążeniowe powinny być stosowane w docelowych optymalnych dawkach, aby zmniejszyć ciśnienie napełniania lewej komory [27]. Również szczególne interwencje zabiegowe (m.in. operacje zastawkowe, MitraClip, implantacje urządzeń wspomagających lewą komore [LVAD, left ventricular assist device], terapia resynchronizacyjna) mogą zmniejszać PH poprzez obniżenie ciśnienia napełniania lewego serca [28]. Analiza hemodynamiki krążenia płucnego w podejmowaniu decyzji terapeutycznych może być bardzo pomocna. Optymalizacja leczenia moczopędnego zwykle prowadzi do zmniejszenia PAWP/LVEDP, ciśnienia w tętnicy płucnej (PAP, pulmonary artery pressure) i TPG [29]. Potwierdzeniem tej tezy może być badanie CHAMPION, w którym wykazano, że przyjęcie w leczeniu chorych wartości PAP (mierzonego przez wszczepione urządzenie) za dodatkowy punkt odniesienia znacząco zmniejszało częstość hospitalizacji związanych z zaostrzeniem zarówno HFREF, jak i HFPEF. Redukcję PAP w tym badaniu uzyskiwano dzięki optymalizacji leczenia HF, w tym korekcie dawek diuretyków [30].

W wytycznych European Society of Cardiology/European Respiratory Society (ESC/ERS) odradza się stosowanie leków dopuszczonych do leczenia PAH w PH-LHD ze względu na brak dowodów na korzystny bilans korzyści i strat. Istnieje hipoteza, iż remodeling naczyń płucnych u pacjentów z HF jest celowy i może być korzystny u osób z PH-LHD, szczególnie w przypadkach, kiedy PH dominuje w obrazie klinicznym. Zastosowanie leków celowanych w PAH prowadzi do rozszerzenia naczyń płucnych i zwięk- szenia płucnego przepływu krwi. Usunięcie komponenty przedwłośniczkowej może dodatkowo zwiększyć podwyższone już u tych chorych PAWP, prowadząc do zaostrzenia $\mathrm{HF}$, a nawet obrzęku płuc [31].

Badania na temat stosowania terapii celowanej w PAH u chorych z PH-LHD są nieliczne, a wyniki na ogół rozczarowujące. Inhalacje NO testowano w leczeniu chorych z ciężkim PH-LHD po implantacji LVAD i po transplantacji serca. U pacjentów z LVAD inhalacje NO powodowały obniżenie PAP i wzrost przepływu w LVAD. W przypadku chorych po transplantacji serca leczenie inhalacjami NO indukowało selektywne zmniejszenie PVR bez wpływu na opór systemowy [32]. W nowszych badaniach stwierdzono, że łączne zastosowanie w okresie pooperacyjnym u chorych z PH po operacjach kardiochirurgicznych inhalacji NO i doustnego podawania sildenafilu było bezpieczne i wiązało się z obniżeniem PAP i PVR bez systemowej hipotonii i zaburzeń stosunku wentylacji do perfuzji [33].

Prostacyklina jest substancją silnie rozszerzająca naczynia wszystkich łożysk naczyniowych. Prostanoidy wykazywały korzystne ostre i długotrwałe efekty hemodynamiczne u pacjentów z PH-LHD włączanych do małych badań. Prowadziły one do zmniejszenia PAP, PAWP i PVR oraz wzrostu $\mathrm{CO}$, ale również do spadku systemowego ciśnienia tętniczego i oporu [34]. W międzynarodowym randomizowanym badaniu (FIRST) 471 pacjentów z ciężką niewydolnością lewej komory (obniżona EF, średnie PAWP $25 \mathrm{~mm} \mathrm{Hg}$ ) leczono dożylnym wlewem epoprostenolu w celu poprawy wydolności fizycznej, jakości życia i zmniejszenia zachorowalności. Badanie to zostało przedwcześnie zakończone, ponieważ leczenie epoprostenolem było związane z silną tendencją do zwiększenia śmiertelności chorych w porównaniu z grupą przyjmującą placebo [35].

Endotelina 1 wykazuje działanie naczynioskurczowe wiążąc się z receptorami obecnymi w komórkach mięśni gładkich naczyń płucnych. Zachęcające wyniki obserwowano w leczeniu stanów ostrych z wykorzystaniem ET antagonistów (bosentan) u chorych z objawową HF. Ciśnienie w tętnicy płucnej, RAP, PCWP, PVR były mniejsze, podczas gdy CO i SV wzrastały [36]. Mimo pozytywnych wyników wstępnych rezultaty badań z bosentanem prowadzonych na szeroką skalę u pacjentów z przewlekłą HF są rozczarowujące. Okazało się bowiem, że brak wymiernych korzyści związanych z tym leczeniem, natomiast zaobserwowano wyraźny wzrost częstości klinicznych i hemodynamicznych wykładników zaostrzenia niewydolności serca podczas leczenia, związany głównie ze zwiększoną retencją płynów [37]. Dostępnych jest niewiele danych dotyczących zastosowania antagonistów receptorów endotelinowych u chorych z PH-HFPEF. Wykazały one, że zastosowanie tych leków wiąże się ze zwiększonym ryzykiem obrzęków obwodowych. Trwa badanie II fazy (MELODY) oceniające bezpieczeństwo i ewentualne korzyści z zastosowania macitentanu u chorych z HFPEF i Cpc-PH. 
Nie słabnie zainteresowanie wykorzystaniem inhibitorów fosfodiesterazy 5 w leczeniu PH-LHD. Zahamowanie fosfodiesterazy typu 5, enzymu degradującego cGMP, powoduje za pośrednictwem szlaku NO/cGMP zwiększoną aktywność kinaz białkowych i aktywuje mechanizmy wewnątrzkomórkowe związane z relaksacją mięśni gładkich, wazodylatacją i zmniejszeniem remodelingu naczyń płucnych. Istnieją dowody na skuteczność i bezpieczeństwo stosowania sildenafilu u chorych ze skurczową HF i PH. W badaniu służącym ocenie 44 pacjentów z HFREF wykazano znaczną poprawę następujących parametrów: średniego PAWP, funkcji i geometrii RV, TAPSE i EF, RAP w trakcie leczenia sildenafilem przez sześć miesięcy w porównaniu z placebo. Ta odpowiedź utrzymywała się przez kolejne 12 miesięcy obserwacji. W badaniu tym po raz pierwszy wykazano, że czynność rozkurczowa i geometria serca mogą być dodatkowymi celami leczenia [38].

Di Salvo nie stwierdził, by stosowanie sildenafilu wiązało się z występowaniem obrzęku płuc, potencjalnego powikłania, do którego może prowadzić zwiększenie powrotu żylnego w obecności zaawansowanej dysfunkcji skurczowej i rozkurczowej lewej komory. Był on dobrze tolerowany, rzadko występowały bóle głowy i zaczerwienienie twarzy [39].

$Z$ jednej strony, w randomizowanym badaniu RELAX, w którym oceniano skuteczność leczenia inhibitorami fosfodiesterazy 5 u osób z HFPEF, wykazano, że stosowanie sildenafilu przez 24 tygodnie w zwiększanych dawkach nie poprawiło szczytowego zużycia tlenu w badaniu ergospirometrycznym (pierwszorzędowy punkt końcowy) ani wydolności fizycznej u pacjentów bez PH [40]. Z drugiej strony, autorzy małych, jednoośrodkowych badań konsekwentnie sygnalizują, że sildenafil poprawia parametry hemodynamiczne i wydolność fizyczną u pacjentów z ciężkim PH w przebiegu zarówno HFREF, jak i HFPEF. W ostatnio opublikowanym badaniu wykazano, że sildenafil poprawia hemodynamikę i wydolność fizyczną u 53 pacjentów z HFPEF i Ipc-PH [41]. Ponadto w toku jest badanie SilHF, którego autorzy pragną wykazać skuteczność sildenafilu wśród pacjentów z niewydolnością serca w II i III klasie NYHA w zakresie poprawy klasy czynnościowej i jakości życia [42].

Alternatywną drogą stymulacji szlaku NO jest zastosowanie stymulatorów rozpuszczalnej cyklazy guanylowej (sCG, soluble guanylate cyclase). Przedstawicielem tej grupy leków jest riociguat, który został zarejestrowany do leczenia chorych z nieoperacyjnym PH o etiologii zakrzepowo-zatorowej. Ma on podwójny mechanizm działania - uczula rozpuszczalną cyklaze guanylową na działanie endogennego NO oraz bezpośrednio ją stymuluje niezależnie od NO. Skutkiem tego dochodzi do rozszerzenia naczyń krwionośnych. W badaniu LEPHT wśród pacjentów z PH w przebiegu HFREF nie udało się osiągnąć głównego punktu końcowego, jakim było obniżenie mPAP, ale wyka- zano znaczący wzrost wskaźnika sercowego (Cl, cardiac index) i objętości wyrzutowej przy braku wpływu na częstość serca oraz systemowe ciśnienie krwi. Uzyskano również znamienne obniżenie płucnego i systemowego oporu naczyniowego [43]. Podobne wyniki uzyskano w badaniu DILATE prowadzonym w grupie chorych z PH-HFPEF [44].

Należy pamiętać, że u pacjentów ze skurczową HF i istotną rozstrzenią lewych jam serca współistnieje funkcjonalna niedomykalność mitralna, która może stanowić istotną przyczynę PH. Niedawno wykazano, że nawet u chorych z bezobjawową czynnościową niedomykalnością mitralną indukowane wysiłkiem PH i dysfunkcja RV wiążą się z gorszym rokowaniem. Właściwe leczenie zabiegowe tej grupy pacjentów, w tym zabiegi z użyciem MitraClip lub CardioBand mogą doprowadzić do znacznej poprawy hemodynamiki krążenia płucnego - redukcji mPAP i PAWP oraz wzrostu Cl. Trwają badania wskazujące, że przezskórna naprawa zastawki mitralnej zmniejsza objawy kliniczne, poprawia wydolność fizyczną i jakość życia oraz redukuje częstość hospitalizacji związanych z HF [45].

\section{Podsumowanie}

Nadciśnienie płucne związane z chorobami lewego serca wynika z zaburzeń funkcji skurczowej i rozkurczowej lewej komory, które prowadzą do wzrostu ciśnienia napełniania lewej połowy serca. Zapoczątkowuje to wiele niekorzystnych zmian patofizjologicznych i czynnościowych w krążeniu płucnym i w końcu w prawym sercu. Wzrastająca częstość występowania chorób lewego serca, w szczególności HFPEF oznacza, że znaczna część pacjentów z niewydolnością serca rozwinie PH. Jest to zagrażające życiu powikłanie, które często pozostaje niedocenione w kardiologii klinicznej. Jego rozpoznanie i leczenie jest niezwykle trudne. $\mathrm{Na}$ szczęście zharmonizowana terminologia i nowa klasyfikacja PH-LHD (Ipc-PH i Cpc-PH) pozwalają na lepszą kwalifikację chorych i powinny zapobiec niewłaściwemu off-label zastosowaniu u chorych z PH-LHD leków celowanych w PAH. Obecne wytyczne dotyczące leczenia są ograniczone do poprawnego leczenia choroby podstawowej i zapobieganiu hospitalizacjom. Nie zaleca się stosowania leków swoistych dla PAH. Do tej pory większość strategii terapeutycznych ukierunkowanych na leczenie PH nie wykazała pozytywnych wyników, choć pierwsze doświadczenia z inhibitorami fosfodiesterazy 5 i sCG wydają się zachęcające. Istnieje wyraźna potrzeba dalszych badań nad mechanizmami leżącymi u podstaw PH-LHD i nowymi opcjami terapeutycznymi, które pomogą stymulować rozwój nowych wytycznych leczenia tej coraz liczniejszej grupy pacjentów.

\section{Konflikt interesów}

Autorzy nie zgłaszają konfliktu interesów. 


\section{Abstract}

Chronic heart failure is a disease with growing importance in modern cardiology. In spite of a significant progress the treatment results are still far from satisfactory. Pulmonary hypertension $(\mathrm{PH})$ is a harbinger of poor prognosis in this group of patients increasing the risk of hospitalisation and death. Pulmonary hypertension secondary to left heart diseases is a result of diastolic and systolic dysfunction leading to increased left ventricular filling pressures. That, in turn, is followed by further unfavourable pathophysiological and functional changes in pulmonary circulation ultimately causing right ventricular failure. Diagnosis and treatment of pulmonary hypertension is not an easy task. Thankfully, the development of diagnostic methods, uniformed terminology and a new classification of pulmonary hypertension allow for faster and more precise diagnosis and qualification of patients to the appropriate clinical subgroup. Right heart catheterization is crucial for the final diagnosis and classification of pulmonary hypertension. Proper methodology of the examination and drawing appropriate conclusions from available haemodynamic and clinical data is essential for further therapeutic management. Most of targeted therapies are addressed to patients with pulmonary arterial hypertension and the administration of these drugs in PH-LHD was either not sufficiently studied in randomized trials or was proved to cause the harm. There is a distinct need for further research on basic mechanisms of PH-LHD as well as on novel therapeutic strategies that may stimulate the development of new guidelines on the treatment of this growing population of $\mathrm{PH}$ patients.

Key words: heart failure, pulmonary hypertension

Folia Cardiologica 2017; 12, 3: 317-325

\section{Piśmiennictwo}

1. Georgiopoulou VV, Kalogeropoulos AP, Borlaug BA, et al. Left ventricular dysfunction with pulmonary hypertension. Part 1: Epidemiology, pathophysiology, and definitions. Circulation: Heart Failure. 2013; 6(2): 344-354, doi: 10.1161/circheartfailure.112.000095.

2. Schmeisser A, Schroetter H, Braun-Dulleaus RC. Management of pulmonary hypertension in left heart disease. Ther Adv Cardiovasc Dis. 2013; 7(3): 131-151, doi: 10.1177/1753944713477518, indexed in Pubmed: 23592742.

3. Galiè N, Humbert M, Vachiery JL, et al. 2015 ESC/ERS Guidelines for the diagnosis and treatment of pulmonary hypertension: the Joint Task Force for the Diagnosis and Treatment of Pulmonary Hypertension of the European Society of Cardiology (ESC) and the European Respiratory Society (ERS): Endorsed by: Association for European Paediatric and Congenital Cardiology (AEPC), International Society for Heart and Lung Transplantation (ISHLT). Eur Heart J. 2016; 37(1): 67-119, doi: 10.1093/eurheartj/ehv317, indexed in Pubmed: 26320113.

4. Hoeper MM, Bogaard HJ, Condliffe R, et al. Definitions and diagnosis of pulmonary hypertension. J Am Coll Cardiol. 2013; 62(25 Suppl): D42-D50, doi: 10.1016/j.jacc.2013.10.032, indexed in Pubmed: 24355641.

5. Miller WL, Grill DE, Borlaug BA. Clinical features, hemodynamics, and outcomes of pulmonary hypertension due to chronic heart failure with reduced ejection fraction: pulmonary hypertension and heart failure. JACC Heart Fail. 2013; 1(4): 290-299, doi: 10.1016/j. jchf.2013.05.001, indexed in Pubmed: 24621932.

6. Gabbay E, Yeow W, Playford D. Pulmonary arterial hypertension is an uncommon cause of pulmonary hypertension in an unselected population: the Armadale echocardiography study. Am J Resp Crit Care Med. 2007; 175: A713.

7. Tatebe S, Fukumoto Y, Sugimura K, et al. Clinical significance of reactive post-capillary pulmonary hypertension in patients with left heart disease. Circ J. 2012; 76(5): 1235-1244, indexed in Pubmed: 22313804.
8. Rosenkranz S. Pulmonary hypertension 2015: current definitions, terminology, and novel treatment options. Clin Res Cardiol. 2015; 104(3): 197-207, doi: 10.1007/s00392-014-0765-4, indexed in Pubmed: 25479818.

9. Vachiéry JL, Adir Y, Barberà JA, et al. Pulmonary hypertension due to left heart diseases. J Am Coll Cardiol. 2013; 62(25 Suppl): D100-D108, doi: 10.1016/j.jacc.2013.10.033, indexed in Pubmed: 24355634.

10. Gerges C, Gerges M, Lang MB, et al. Diastolic pulmonary vascular pressure gradient: a predictor of prognosis in "out-of-proportion" pulmonary hypertension. Chest. 2013; 143(3): 758-766, doi: 10.1378/ /chest.12-1653, indexed in Pubmed: 23580984.

11. Bursi F, McNallan SM, Redfield MM, et al. Pulmonary pressures and death in heart failure: a community study. J Am Coll Cardiol. 2012; 59(3): 222-231, doi: 10.1016/j.jacc.2011.06.076, indexed in Pubmed: 22240126.

12. Melenovsky V, Hwang SJ, Redfield MM, et al. Left atrial remodeling and function in advanced heart failure with preserved or reduced ejection fraction. Circ Heart Fail. 2015; 8(2): 295-303, doi: 10.1161/ /CIRCHEARTFAILURE.114.001667, indexed in Pubmed: 25593126.

13. Chen Y, Guo H, Xu D, et al. Left ventricular failure produces profound lung remodeling and pulmonary hypertension in mice: heart failure causes severe lung disease. Hypertension. 2012; 59(6): 1170-1178, doi: 10.1161/HYPERTENSIONAHA.111.186072, indexed in Pubmed: 22508832.

14. Rosenkranz S, Gibbs JS, Wachter R, et al. Left ventricular heart failure and pulmonary hypertension. Eur Heart J. 2016; 37(12): 942-954, doi: 10.1093/eurheartj/ehv512, indexed in Pubmed: 26508169.

15. Melenovsky V, Hwang SJ, Lin G, et al. Right heart dysfunction in heart failure with preserved ejection fraction. Eur Heart J. 2014; 35(48): 3452-3462, doi: 10.1093/eurheartj/ehu193, indexed in Pubmed: 24875795.

16. Al-Naamani N, Preston IR, Paulus JK, et al. Pulmonary arterial capacitance is an important predictor of mortality in heart failure with 
a preserved ejection fraction. JACC Heart Fail. 2015; 3(6): 467-474, doi: 10.1016/j.jchf.2015.01.013, indexed in Pubmed: 26046840.

17. Shin JT, Semigran MJ. Heart failure and pulmonary hypertension. Heart Fail Clin. 2010; 6(2): 215-222, doi: 10.1016/j.hfc.2009.11.007, indexed in Pubmed: 20347789.

18. Thenappan T, Shah SJ, Gomberg-Maitland M, et al. Clinical characteristics of pulmonary hypertension in patients with heart failure and preserved ejection fraction. Circ Heart Fail. 2011; 4(3): 257-265, doi: $10.1161 /$ CIRCHEARTFAILURE.110.958801, indexed in Pubmed: 21411741.

19. Ghio S, Temporelli PL, Klersy C, et al. Prognostic relevance of a non-invasive evaluation of right ventricular function and pulmonary artery pressure in patients with chronic heart failure. Eur J Heart Fail. 2013; 15(4): 408-414, doi: 10.1093/eurjhf/hfs208, indexed in Pubmed: 23307814.

20. Hoeper MM, Lee SH, Voswinckel R, et al. Complications of right heart catheterization procedures in patients with pulmonary hypertension in experienced centers. J Am Coll Cardiol. 2006; 48(12): 2546-2552, doi: 10.1016/j.jacc.2006.07.061, indexed in Pubmed: 17174196.

21. Drazner MH, Velez-Martinez M, Ayers $\mathrm{CR}$, et al. Relationship of right-to left-sided ventricular filling pressures in advanced heart failure: insights from the ESCAPE trial. Circ Heart Fail. 2013; 6(2): 264-270, doi: 10.1161/CIRCHEARTFAILURE.112.000204, indexed in Pubmed: 23392790.

22. Ryan JJ, Rich JD, Thiruvoipati T, et al. Current practice for determining pulmonary capillary wedge pressure predisposes to serious errors in the classification of patients with pulmonary hypertension. Am Heart J. 2012; 163(4): 589-594, doi: 10.1016/j.ahj.2012.01.024, indexed in Pubmed: 22520524.

23. LeVarge BL, Pomerantsev E, Channick RN. Reliance on end-expiratory wedge pressure leads to misclassification of pulmonary hypertension. Eur Respir J. 2014; 44(2): 425-434, doi: 10.1183/ /09031936.00209313, indexed in Pubmed: 24925918.

24. Boerrigter BG, Waxman AB, Westerhof $\mathrm{N}$, et al. Measuring central pulmonary pressures during exercise in COPD: how to cope with respiratory effects. Eur Respir J. 2014; 43(5): 1316-1325, doi: 10.1183/09031936.00016913, indexed in Pubmed: 24177003.

25. Ryan JJ, Rich JD, Thiruvoipati T, et al. Current practice for determining pulmonary capillary wedge pressure predisposes to serious errors in the classification of patients with pulmonary hypertension. Am Heart J. 2012; 163(4): 589-594, doi: 10.1016/j.ahj.2012.01.024, indexed in Pubmed: 22520524.

26. Konopka M, Braksator W. Nadciśnienie płucne - postępy w diagnostyce i leczeniu. Fam Med Primary Care Rev. 2013; 15(4): 561-566 .

27. Rosenkranz S, Bonderman D, Buerke M, et al. Pulmonary hypertension due to left heart disease: updated Recommendations of the Cologne Conse-nsus Conference 2011. Int J Cardiol. 2011; 154 Suppl 1: S34-S44, doi: 10.1016/S0167-5273(11)70491-0, indexed in Pubmed: 22221972.

28. Kutty RS, Parameshwar J, Lewis C, et al. Use of centrifugal left ventricular assist device as a bridge to candidacy in severe heart failure with secondary pulmonary hypertension. Eur J Cardiothorac Surg. 2013; 43(6): 1237-1242, doi: 10.1093/ejcts/ezs678, indexed in Pubmed: 23345184.

29. Kalogeropoulos AP, Georgiopoulou W, Borlaug BA, et al. Left ventricular dysfunction with pulmonary hypertension: part 2: prognosis, noninvasive evaluation, treatment, and future research. Circ
Heart Fail. 2013; 6(3): 584-593, doi: 10.1161/CIRCHEARTFAILURE.112.000096, indexed in Pubmed: 23694772.

30. Abraham WT, Adamson PB, Bourge RC, et al. Wireless pulmonary artery hemodynamic monitoring in chronic heart failure: a randomized controlled trial. Lancet. 2011; 377: 658-666.

31. Haddad F, Kudelko K, Mercier 0 , et al. Pulmonary hypertension associated with left heart disease: characteristics, emerging concepts, and treatment strategies. Prog Cardiovasc Dis. 2011; 54(2): 154-167, doi: 10.1016/j.pcad.2011.06.003, indexed in Pubmed: 21875514.

32. Kieler-Jensen N, Lundin S, Ricksten SE. Vasodilator therapy after heart transplantation: effects of inhaled nitric oxide and intravenous prostacyclin, prostaglandin E1, and sodium nitroprusside. J Heart Lung Transplant. 1995; 14(3): 436-443, indexed in Pubmed: 7654728.

33. Matamis D, Pampori S, Papathanasiou A, et al. Inhaled NO and sildenafil combination in cardiac surgery patients with out-of-proportion pulmonary hypertension: acute effects on postoperative gas exchange and hemodynamics. Circ Heart Fail. 2012; 5(1): 47-53, doi: 10.1161/CIRCHEARTFAILURE.111.963314, indexed in Pubmed: 22057829.

34. Sueta CA, Gheorghiade M, Adams KF, et al. Safety and efficacy of epoprostenol in patients with severe congestive heart failure. Epoprostenol Multicenter Research Group. Am J Cardiol. 1995; 75(3): 34A-43A, indexed in Pubmed: 7840053.

35. Shah MR, Stinnett SS, McNulty SE, et al. Hemodynamics as surrogate end points for survival in advanced heart failure: an analysis from FIRST. Am Heart J. 2001; 141(6): 908-914, doi: 10.1067/ /mhj.2001.115299, indexed in Pubmed: 11376303.

36. Sütsch G, Kiowski W, Yan XW, et al. Short-term oral endothelin-receptor antagonist therapy in conventionally treated patients with symptomatic severe chronic heart failure. Circulation. 1998; 98(21): 2262-2268, indexed in Pubmed: 9826312.

37. Hefke T, Zittermann A, Fuchs U, et al. Bosentan effects on hemodynamics and clinical outcome in heart failure patients with pulmonary hypertension awaiting cardiac transplantation. Thorac Cardiovasc Surg. 2012; 60(1): 26-34, doi: 10.1055/s-0030-1250726, indexed in Pubmed: 21432755.

38. Guazzi M, Vicenzi M, Arena R, et al. Pulmonary hypertension in heart failure with preserved ejection fraction: a target of phosphodiesterase-5 inhibition in a 1-year study. Circulation. 2011; 124(2): 164-174, doi: 10.1161/CIRCULATIONAHA.110.983866, indexed in Pubmed: 21709061.

39. Di Salvo TG. Pulmonary hypertension and right ventricular failure in left ventricular systolic dysfunction. Curr Opin Cardiol. 2012; 27(3): 262-272, doi: 10.1097/HCO.0b013e3283522098, indexed in Pubmed: 22495594.

40. Borlaug BA, Lewis GD, McNulty SE, et al. Effects of sildenafil on ventricular and vascular function in heart failure with preserved ejection fraction. Circ Heart Fail. 2015; 8(3): 533-541, doi: 10.1161/CIRCHEARTFAILURE.114.001915, indexed in Pubmed: 25782985.

41. Wu X, Yang Te, Zhou Qi, et al. Additional use of a phosphodiesterase 5 inhibitor in patients with pulmonary hypertension secondary to chronic systolic heart failure: a meta-analysis. Eur J Heart Fail. 2014; 16(4): 444-453, doi: 10.1002/ejhf.47, indexed in Pubmed: 24464734.

42. Cooper TJ, Guazzi M, Al-Mohammad A, et al. Sildenafil in Heart failure (SilHF). An investigator-initiated multinational randomized controlled clinical trial: rationale and design. Eur J Heart Fail. 
2013; 15(1): 119-122, doi: 10.1093/eurjhf/hfs152, indexed in Pubmed: 23097067.

43. Bonderman D, Ghio S, Felix SB, et al. Left Ventricular Systolic Dysfunction Associated With Pulmonary Hypertension Riociguat Trial (LEPHT) Study Group. Riociguat for patients with pulmonary hypertension caused by systolic left ventricular dysfunction: a phase $\mathrm{Ilb}$ double-blind, randomized, placebo-controlled, dose-ranging hemodynamic study. Circulation. 2013; 128(5): 502-511, doi: 10.1161/ /CIRCULATIONAHA.113.001458, indexed in Pubmed: 23775260.
44. Bonderman D, Pretsch I, Steringer-Mascherbauer R, et al. Acute hemodynamic effects of riociguat in patients with pulmonary hypertension associated with diastolic heart failure (DILATE-1): a randomized, double-blind, placebo-controlled, single-dose study. Chest. 2014; 146(5): 1274-1285, doi: 10.1378/chest.14-0106, indexed in Pubmed: 24991733.

45. Lancellotti P, Magne J, Dulgheru R, et al. Clinical significance of exercise pulmonary hypertension in secondary mitral regurgitation. Am J Cardiol. 2015; 115: 1554-1561. 